\title{
Improving Children's Emotional Intelligence Through Kinesthetic Learning Strategy at Al Hidayah Kindergarten Aia Tabik Kamang Magek Sub District Agam
}

\author{
Nur Hazizah ${ }^{1, *}$, Prima Aulia $^{1}$ \\ ${ }^{I}$ Department of Early Childhood Education, Faculty of Education, Universitas Negeri Padang,Padang, Indonesia \\ *Corresponding author. Email: Nur_hazizah@fip.unp.ac.id
}

\begin{abstract}
This research aims to undergo an experiment on kinesthetic learning strategy in developing children's emotional intelligence. The subjects were children ranged from 4-5 years at Al Hidayah kindergarten Aia Tabik Kamang Magek Subdistrict Agam. The data collected using observation with checklist and documentation. Findings of the research showed that children's emotional intelligence has improved after the kinesthetic learning strategy was implemented. The table of the result on every subject proved that kinesthetic learning strategy has improved the children's emotional intelligence as much as 24,67 . Based on the statistic analysis at a significant level of 5\%,t0 is greater than tt, means that the alternative hypothesis is accepted. Therefore, kinesthetic learning strategy has improved children's emotional intelligence at Al Hidayah kindergarten Aia Tabik Kamang Magek Sub district, Agam.

Keywords: kinesthetic learning strategy, emotional intelligence, intelligence development
\end{abstract}

\section{INTRODUCTION}

Emotion is a state of an individual at particular instance reflected by moderate to intense gradation, such as very happy or very sad [1]. One of the factors in children's emotional development is teacher. Goleman stated that the basics of emotions are anger, sadness fear, shame, and love. When children begin to show their emotion, it shows in a variety of forms, like positive and negative emotions. Children at 4-5 years old can convey and develop their positive emotions. They can control themselves, manifest empathy, and appreciate others, being fearless and responsible for themselves and others.

Findings on observation and interview conducted in childhood education institution (hereafter referred to as PAUD) Al hidayah kindergarten Aia Tabik Kamang Magek Sub district Agam, showed that many children have not been able to control their emotions. For instance, they tend to be shy, have difficulty in expressing their emotions, yell, and are unable to perceive their feelings and others, impatient to wait for their turn, less responsible and resistant.

This research offers a new strategy for teachers to develop children's emotional intelligence, namely the kinesthetic learning strategy. The strategy is applied in play activity and designed in the form of games such as creative movement, running, dancing, building and crafting which are performed individually or collectively.

Based on this background, the writer conducted a test or experiment to develop children's emotional intelligence through kinesthetic learning strategy in the childhood education institution

\section{REVIEW OF LITERATURE}

\subsection{The concept of emotional intelligence in early childhood}

Shapiro cited by Firdaus[3] explained that emotion is a human psychiatric condition. Emotion, due to its psychological nature, can only be observed by emotional expressions such as sadness, happiness, anxiety, hatred and other expressions. As every child manifests different emotional condition, they have different ways to manage it. One child may express his sadness by crying but another takes crying like a whiny act. Meanwhile, the other children may express their sadness with sorrowful facial expression or being alone, not to mention their social-emotional conditions [4].

According to Hurlock[5], there are two types of emotions expressed frequently in childhood, fear, and anger. The 
two kinds of emotions are derived from negative emotion. When children feel fearful, they express it by crying, screaming or fainting at an extreme situation. If they get angry, they throw things out, hit or hurt themselves and others.

Children's emotional development includes recognizing what feelings and emotions they have been through, understanding how and why it occurs, identifying their feeling as well as the others' and developing the effective way to manage them. As they grow up, children's emotional development also becomes more complex depending on their experience. Thus, teachers need to implement intelligence development to help the children manage their emotions as it is important for their mental health.

Emotion is an important aspect of childhood. Through emotions, children can stay focused, gain energy and organize their thoughts.

\subsection{Learning strategy for early childhood}

According to David in Sanjaya, a strategy is defined as a plan containing activity list which is designed to achieve certain education purpose. Kemp in Sanjaya defined learning strategy as a learning activity conducted by teacher and learner to attain an effective and efficient purpose. Dick and Carey also asserted that learning strategy is a set of learning material and procedure used to produce a learning outcome.

Furthermore, Suparman in Dedi argued that learning strategy is a combination of activities order, method of organizing learning materials, tools and time used during the learning process to achieve certain learning purpose. Gerlach and Ely in Dedi also affirmed that learning strategy is techniques selected to deliver learning method in a certain learning environment

\subsection{Kinesthetic learning strategy}

To help children develop towards the optimal and conducive direction, teachers and parents need to stimulate the children with various learning strategies during the learning process. Teachers are expected to stimulate and involve children sensory and sense by integrating numerous learning strategies during the learning process. Leaning strategy needs to be integrated with distinct way when conducting activities as it has different function and form. Several activities that can be developed into various strategies as stated by Saputra \& Rudyanto[6] are 1) exploration activity 2) mutual activity 3 ) problem-solving activity 4) hunting activity 5) discussion 6) demonstration activity 7) direct instruction 8) cooperative activity.

Discussion means that teacher guides the learners in conversation, encourage them to express themselves and communicate straightforward. Meanwhile, demonstration means teacher gives example to the learners and it generally involves one person to demonstrate to others.
As described above, we can conclude that learning activity can be integrated with diverse strategies and selected following the children's intelligence development

\section{METHOD OF THE RESEARCH}

The method used in this research was experimental research. Experimental research aims to seek the influence of a certain treatment on variables in a controlled environment [7]. The researcher manipulates the variables which are called as treatment. The quasi-experimental design used was time-series design. The group selected for this research was one group which was not randomly selected before the treatment.

\section{RESULT}

The experiment was carried out in Al hidayah kindergarten Aia Tabik Kamang Magek Sub district Agam using kinesthetic learning strategy. The post-test showed a more significant transformation compared to pre-test as children placed in the good category. The alternative hypothesis (Ha) indicated that kinesthetic learning strategy to be a better strategy in developing children's emotional intelligence of group B2 at Hidup Bersama Galogandang kindergarten was accepted. Null hypothesis (Ho) indicated that kinesthetic learning strategy to be not better in developing children's emotional intelligence of group B1 Al hidayah kindergarten Aia Tabik Kamang Magek was rejected. From the result, we can confirm that kinesthetic learning strategy is a better strategy in developing children's intelligence development of group B1 Al hidayah kindergarten Aia Tabik Kamang Magek at the significant level of $1 \%(9,28>3,25)$.

\section{DISCUSSION}

Based on the result, children of group B1 Al hidayah kindergarten Aia Tabik Kamang Magek have successfully utilized the kinesthetic learning strategy to develop emotional intelligence. The transformation showed that, before the treatment, children encountered some problems in emotional intelligence, for instance, failure in identifying their emotions, control their emotions, motivate themselves, manifest empathy and manage a relationship. After the strategy was implemented, the learning process is not only involving children physically but also emotionally.

Kinesthetic learning strategy is a creative approach to influence children's emotional intelligence. It supports children's emotional aspect and encourages the other aspects to be well-developed. As kinesthetic learning strategy provides environment corresponding with children's' characteristics, the implementation becomes 


\section{REFERENCES}

way, children are not only developing in IQ but also EQ.

\section{CONCLUSION}

Result of the research shows that kinesthetic learning strategy is one of the methods to develop children's emotional intelligence. This strategy has been successfully proved from the experiment, particularly in several aspects; identifying emotion, control emotion, selfmotivation, empathy manifestation, and relationship maintenance.

\section{SUGGESTION}

Teachers are expected to be able to develop children's intelligence as a whole using a proper and appropriate learning strategy. This is because learning strategy determines the success of a learning activity particularly for the development of children's emotional intelligence.
[1] Y. Jahja, Psikologi Perkembangan. Jakarta: Prenada Media, 2011.

[2] L. E. Shapiro, Mengajarkan Emotional Intelligence pada Anak. Jakarta: Gramedia, 1998.

[3] S. Firdaus, "Peranan Orang Tua dalam Mendidik Kecerdasan Emosional Anak Usia 6-12 Tahun dalam Perspektif Pendidikan Islam," UIN Syarif Hidayatullah Jakarta, 2016.

[4] Suyadi, Psikologi Belajar Anak Usia Dini. Yogyakarta: Pedagogia, 2010.

[5] M. Riana, Emosi Anak Usia Dini dan Strategi Pengembangannya. Jakarta: Kencana, 2011.

[6] Y. M. Saputra and Rudyanto, Pembelajaran Kooperatif untuk Meningkatkan Keterampilan Anak TK. Jakarta: Depdiknas, 2005.

[7] Sugiyono, Metode Penelitian Kuantitatif, Kualitatif dan $R \& D, 15$ th ed. Bandung: Alfabeta, 2012. 